\title{
Start and run a medical dining club
}

\author{
J H Baron
}

British medicine has many curious customs. One of the least known and most idiosyncratic is the dining club. A club can be scientific, semiscientific, or simply sybaritic. I explain here the origin of these clubs and give detailed advice on how to start one and run it successfully. I do not cover alumni or surgical travelling clubs: they present no problems. Nor do I discuss groups such as the Breathing Club, whose members respire and cerebrate, but neither eat nor drink.

\section{History}

Most of our famous professional societies began as a small group of friends with a common interest, who discussed, drank, and dined together regularly: Aubrey's "sodality in a tavern," or Dr Johnson's “an assembly of good fellows meeting under certain conditions." With a small membership renewed only on resignation or death such clubs may survive for centuries. Once the membership of the club expands into hundreds or thousands with the advance of the particular specialty, then the members cannot all dine together intimately. There is then a need for a club within a club and a new small fraction of the larger society comes together to meet, drink, and dine with one another. Thus the British Society of Gastroenterology began with 39 members in 1937 but now has 1500 , so that on the evening before its annual dinner smaller groups meet, each with its own theme.

Clubs go back three centuries. Robert Boyle's Invisible College of experimental philosophers met weekly from 1645, often in the Bull's Head Tavern in Cheapside. By 1648 it had a satellite, the Philosophical Society of Oxford, a 30 member Greate Clubbe. In 1660 these two amalgamated to become the Royal Society, with 55 members, now grown to 1105 .

After the Wednesday meeting groups of fellows supped at different taverns, such as the Crowne Taverne Club, the Club at the Sun, Halley's Club, and the Virtuosoe's Club at Jonathan's Tavern in Cornhill. The records of the present Royal Society Club date from 1743, with eight members dining on fish and pudding with porter for half a crown (12.5p). ${ }^{12}$ Membership increased to 40 in 1748, 66 in 1900, and later 75 . The club now meets for dinner twice a year, with no formal business except the toast to the "arts and sciences." At its 7573 rd dinner in 1974 it was agreed that women should be allowed membership.

A group of scientists and technologists in Birmingham met together in 1757 and became a formal circle in 1766. Dinner at Matthew Boulton's house was always followed by scientific discussion. This Lunar Society met every full moon for ease of travelling at night. Engineers started to dine on Friday evenings in 1771 at the King's Head Tavern before forming the Smeatonian Society of Civil Engineers. The Society of Antiquaries started their dining club in 1774. The Royal Society of Edinburgh, founded in 1783, had its own club from 1820, and others briefly (New Club 1832-40, Supper Club 1834-5). ${ }^{3}$

Of the social clubs who have their own buildings, the oldest is White's (1693), and there are several others of the mid-eighteenth century, such as Boodle's (1762)
Menu of the Royal Society Club 2 24 March $1747 / 8$

\section{Fresh Salmon Lobster Sauce}

Cods Head

Pidgeon Pye

Calves Head

Bacon \& Greens

Fillett of Veal

Chine of Pork

Plumb Pudding

Apple Custard

Butter \& Cheese

FIG 1-Menu of the Royal Society Club, 24 March $1747^{*}$

and Brook's (1764). Dining clubs, however, usually began in taverns, such as the Dilettanti (1732), now meeting at Brook's, or the artist-governors of the Foundling Hospital (1746), the forerunners of the Royal Academy of 1768. Dr Johnson and Sir Joshua Reynolds founded the Literary Club in 1764, with nine members dining each Monday at $7 \mathrm{pm}$ at the Turk's Head. ${ }^{4}$

The Royal College of Physicians of London had at least two dining clubs, the younger of which was founded before 1764. They merged in 1834 and were still going strong in 1909..$^{5}$ Many of the early minute books of these clubs have not survived. The early records of the Medical Club, afterwards known as the Sydenham Club, are said to have been stolen by a footpad from one of the first secretaries walking home across the park, but its account books date from 1796. Wagers were common-for example, in 1854, "that Miss Nightingale is not married by the next meeting," and, "that Miss Nightingale has a child by this day twelvemonth." $"$ The club still numbers 18 , six each of physicians, surgeons, and "apothecaries." The St Alban's medical club, named after the tavern where it first met, has records dating back to 1789 . It now has $^{7}$ seven each of physicians, surgeons, and apothecaries, dines three times a year, and occasionally dines together with its old rival the Sydenham Club.

Several other clubs have mixed family doctor or specialist membership. The Chelsea Clinical Society was founded in 1896 with nine members for informal discussion about medical problems: "whisky should be provided, but no women." ${ }^{8}$ By 1910 there were over 100 members and formal, clinical, and pathological presentations and volumes of published proceedings. It now has $\mathbf{3 0 0}$ members dining formally (with spouses) five times a year. The Hunterian goes back to 1819 and now has 500 members with 10 dinners a year, as well as the Hunterian Oration at the Royal College of Surgeons.

Some clubs are confined to a particular city or specialty. Thus Oxford has the Circle of Willis (1920s) and the breakaway Bundle of His; each dines every term. Cambridge has the Carphologists; Edinburgh
J H Baron, FRCP, senior

lecturer

BrMed f 1990;300:110-2 
has the Aesculapian (1773) with 11 FRCP and 11 FRCS members dining twice a year. There are also the Royal Medico-Chirurgical, Coulston, and Harveian clubs. General practitioners just south of Hyde Park formed a Sloane Medical Society in 1973. Among the Orthopaedic clubs are the Girdlestone, LippmanKessel, Arbuthnot Lane, Percival Pott, Sesamoid, Innominate, and Nibblers, some of which were started by peer groups of trainees who continue to meet once or twice a year to discuss clinicopathological problems, followed by dinner with spouses.

One medical club was started by the government. After the 1914-18 war the Ministry of Pensions was faced with major economic pressures from those said to be disabled from heart disease. In 1920 the ministry appointed regional cardiological advisers who also met in committee in London from time to time. In 1922 John Cowan turned this group into a 15 member Cardiac Club, which became the British Cardiac Society in $1937 . .^{10}$

The Dublin Biological Club was founded in Trinity College, Dublin in 1872 "to consider the morbid and healthy conditions of animal and vegetable life." Members were originally 14 , then 18 , and later 30 . The club met weekly from October to June, and each member had to present a paper at least once a year. Refreshment was at first limited to light ale, but later there were annual dinners, followed by kite-flying, quoits, and firing with $\cdot 22$ bore rifles at empty champagne bottles.

Most clubs last only for the active lives of their founders and then are forgotten in the absence of any surviving papers. Fortunately, one is documented. ${ }^{13}$ The Hexagon Club was founded for six neurologists by Sir Charles Symonds at a dinner at his Wimpole Street home on 30 April 1930 with Russell Brain, Hugh Cairns, Macdonald Critchley, Derek Denny-Brown, and George Riddoch. All were connected with the National Hospital for Nervous Diseases, Queens Square. They chose to meet regularly at a neutral site, the Great Central Hotel. Conversation was general before and during the dinner, but after dinner at each meeting one member (in turn alphabetically) gave a 20 to 30 minute paper followed by a fierce discussion. Many of these papers, much improved by this rehearsal, appeared in Brain, others disappeared without trace. The club occasionally had foreign guestsFoerster (1931, 1932), Lhermitte (1934), and Broewer (1936). The club ended at the advent of the second world war.

\begin{tabular}{|c|}
\hline Carte de Vins \\
Old Chablis \\
Milk Punch \\
Madeira (1857) \\
Johannisberg (1862) \\
Perrier Jouet \\
(1874) \\
Amontillado \\
Chateau Lafitte \\
(1875) \\
Martinez Port \\
(1865) \\
Boulestin's Cognac \\
(I810) \\
Kümmel \\
Café
\end{tabular}

FIG 2-Menu of the College Club, Burlington Hotel, 22 February 1897, when the Prince of Wales dined

\section{Conclusion}

If you work in an exciting new field and want to talk freely in a congenial ambience with a few colleagues then consider starting a medical dining club. Find an equally gregarious and obsessional friend to help; the more literate of the two can become secretary, the more numerate treasurer. Then write round to suitable prospective members to come to a dinner to discuss your proposal and the future is yours. The following appendices may help.

\section{Appendix I-Model rules for a semiscientific club}

1 Name-This association shall be called the Navel Club in honour of Sir Nathaniel Navel, 1750-1851.

2 Object-This club is constituted to provide opportunities for those interested in the secretions of the umbilicus to meet for discussion and fellowship.

3 Meetings-The club will hold at least one and as many meetings each year as the committee decides. Meetings will usually be held on the evening before the annual meeting of the British Society of Omphalology. Each meeting will consist of a dinner, of which members will be given due notice by the secretary so that they can pay the treasurer in advance if they are attending. Members may bring to the dinner, by prior notification, guests interested in the secretions of the umbilicus. Speakers and topics for discussion will be decided by the committee.

4 Ordinary membership-Persons domiciled in Britain with a major interest in the secretions of the umbilicus are eligible for ordinary membership of the club. Founder members will be selected at a foundation meeting. Additional members may be elected at any meeting of the club after prior notice to the secretary with the candidate's name and umbilical interest and with the signatures of a proposer and seconder. Ordinary membership is limited to 50 .

5 Senior members-Ordinary members automatically become senior members on their 65 th birthday.

6 Honorary membership-The club may elect to honorary membership those ineligible for ordinary membership because of domicile abroad. Honorary members have all the privileges of membership but shall not pay a subscription.

7 Corresponding members-Ordinary members who take up domicile abroad automatically become corresponding members with all the privileges of membership.

8 Subscription-On election each member shall pay to the treasurer a life subscription of $£ 5.00$.

9 Finance-The club shall be financed by contributions from its members. Grants from other organisations and donations from persons desiring to support the club shall be accepted at the discretion of the committee.

10 Management-The business of the club shall be conducted by the committee, which will have sole control in all matters relating to the club. The committee shall consist of the president, the secretary, the treasurer, and two additional members. Two members of the committee shall constitute a quorum.

11 Election of officers-The president shall be elected annually and is not eligible for reappointment. The secretary and treasurer should be elected annually and be eligible for reappointment. The two other members of the committee shall serve for three years and shall not be eligible for immediate reappointment.

12 General meetings - The club will hold an inaugural meeting to draw up the rules of the society and thereafter shall hold an annual general meeting at 
which 10 members shall constitute a quorum. At the annual general meeting reports of the treasurer and secretary shall be presented and the officers elected.

13 Amendments to rules-The rules of the club can be amended at any annual general meeting when notice of proposed changes have been given to each member at least two weeks previously. No changes shall be made unless two thirds of the voting membership are in favour.

\section{Notes}

Rule 1-A constitution is essential for any club, if only to satisfy a bank manager on opening an account.

Rule 2-Ensure that members pay in advance. A scientific, or even a semiscientific, club should have a theme to each dinner, either a discussion paper by a member or guest or a debate carefully argued by a proposer and an opposer on a topic made known to the membership in the annual notice. A toast to "The Queen" can be followed by one in honour of the founder, "The Memory of Nathaniel Navel." This provides an opportunity for some historical references to the development of omphalology in the city in which the club is dining, or the country of origin or domicile of the guest of honour, with some appropriate remarks on the life and times of the founder.

Rule 4-Do not have ordinary members from abroad. Scientific or semiscientific societies should not blackball new members, and in practice it is advisable for the committee to recommend to the postprandial annual general meeting candidates to fill vacancies arising from death, resignation, emigration, or seniority. Members need not come every year: it is more enjoyable and intimate if they do not so that the members, including guests, are less than 40 . Members who stop coming usually resign voluntarily, or can be so persuaded.

Rule 6-Limit honorary membership to those from overseas, usually one each year, and avoid the invidious task of selecting Britons for honours.

Rule 8-The club finances itself from the monies gained from dinners, but needs a small working capital obtained from an entry fee, which avoids the effort and expense of collecting annual subscriptions.

Rule 9-Clubs are often offered hospitality by industry. The committee should consider carefully whether doctors should dine at the expense of others.

Rule 10-The business of the club can usually be managed by the secretary in, say, 10 hours a year. The committee need never meet, but its members can be asked by post to nominate the next president, guest of honour, new members, topics, and debaters. The secretary and the treasurer should stay for years if they are efficient but must be subject to formal reappointment each year.

\section{Appendix 2-Model rules of a sybaritic club}

1 The club shall be called the Sir Lancelot Spratt Dining Club.

2 It shall be limited to 15 members, who shall be proposed and elected by the members.

3 It shall hold not less than one dinner each year, at which members will preside in rotation.

4 One member shall be elected as president for one year only; another shall be elected as secretary/ treasurer for one year and be eligible for re-election. The secretary shall keep the minutes, incorporating the menu of the dinner and the signatures of the members present.

5 A member absent over two consecutive years shall be deemed to have offered his or her resignation.

6 Members attaining the age of 70 years (or 65) shall become senior members and will not be counted within the limits of 15 members of the club, nor will they be liable to forced resignation under rule 5 .

7 Each member may propose one name for any vacancy. The secretary shall send a list of such proposals to all members, who shall record their vote(s) according to the number of vacancies and return the ballot paper to the secretary. A member may vote against any name on the list by striking it out, and one such adverse vote shall exclude that proposal. A second ballot shall then take place on those proposals which scored most votes on the first ballot, and the list on the second ballot should contain one more name than the number of vacancies. This list should be circulated to all members to vote as before, but no name can be excluded on the second or subsequent ballot. Any problems in election shall be solved at the next club dinner under the direction of the president, who shall have a casting vote.

8 Any changes to the rules shall be forwarded to the secretary, proposed and seconded, so that a postal ballot can be conducted with two thirds of the membership being necessary for the change to be agreed.

Notes

Rule 2-A sybaritic dining club must be small enough to dine around one table, about six to 18 in number.

Rule 3-Most clubs dine annually and some three or four times a year.

Rule 4-The president should be changed annually. The secretary should remain in post for years.

Rule 5-A small, closely knit club does not want members who come only occasionally. Their membership should be deemed to have lapsed after their absence for two consecutive years.

Rule 6-Older members may find it difficult to come each year and should be encouraged to come whenever they can.

Rule 7-New members must be acceptable to everyone else, and most clubs operate a "one blackball excludes" rule. Some are more tolerant and two blackballs are needed as veto.

Medical dining clubs have limited membership and do not welcome publicity. I am grateful to club archivists, secretaries, and members for help. I also thank Mr Robin Price, deputy librarian of the Wellcome Institute for the History of Medicine, for his scrutiny.

1 Geikie RA. Royal Society Club. The record of a London dining club in the eighteenth and nineteenth centuries. London: Macmillan, 1917.

2 Allibone TE. The Royal Society and its dining clubs. Oxford: Pergamon, 1976. 3 Guthrie D. A short history of the Royal Society Club of Edinburgh 1820-1962. Edinburgh: privately printed, 1962.

4 Murdoch T. Talk of the Town. Countrv Life 1988;182:180-1.

5 Payne JF. History of the College Club of the Royal College of Phvsicians of London. London: privately printed, 1909.

6 Wellcome Institute for the History of Medicine. The Medical Club. In: A Wellcome Institute for the History of Medicine. The
vision of history. London: Wellcome Trust, 1986:24.

7 Price R. St Albans Medical Club. F Internat Wine Food Soc 1979;6:7-17.

8 Harvey W. A history of the Chelsea Clinical Society. London: privately printed, 1962.

9 Cowan J. Some notes on the Cardiac Club. Br Heart 7 1939;1:97-104

10 Campbell $M$. The British Cardiac Society and Cardiac Club. Br Heart $\mathrm{g}$ 1962;24:673-95

11 Bewley G. An account of the Biological Club. Irish f Med Sci 1960;409:1-15.

12 Foot AW. Reminiscences of the Dublin Biological Club. Dublin 7 Med Sci 1892;93:425-41

13 Critchley M. Posthumous papers of the Hexagon Club. In: The Citadel of the senses and other essays. New York: Raven Press, 1985;109-20. 